\title{
PEMBERDAYAAN MASYARAKAT DALAM PENGELOLAAN HASIL PERIKANAN DI KELURAHAN SUMPANG BINANGAE KABUPATEN BARRU
}

\author{
Zulfan Nahruddin ${ }^{1}$ \\ ${ }^{1}$ Program Studi Ilmu Pemerintahan Fakultas Ilmu Sosial dan Ilmu Politik \\ Universitas Hasanuddin Makassar \\ Jl. Perintis Kemerdekaan Km. 10, Makassar \\ Telp. 0411-586200/ Fax. 0411-586200 \\ zulfannahruddin@gmail.com
}

\begin{abstract}
This study aims to investigate the implementation of community empowerment in the management of the fishery in Sub Sumpang Binangae Barru. The method used is a qualitative descriptive study. The results of this study indicate that the strengthening of the funding for the fishing industry is quite beneficial for fisheries business there is ease access to funding obtained. Empowering local government in terms of packaging and help to improve the promotion of business products processing of fishery products to various areas, provision of facilities and infrastructure business to business operators of industrial shredded fish is quite effective but the implementation of the guidance by the local governments have not been implemented on an ongoing basis in order to increase the economic value added the businesses that have been fostered by the government.
\end{abstract}

Keywords : empowerment, community, management of the fishery

\begin{abstract}
ABSTRAK
Tujuan penelitian ini untuk mengetahui pelaksanaan pemberdayaan masyarakat dalam pengelolaan hasil perikanan di Kelurahan Sumpang Binangae Kabupaten Barru. Metode yang digunakan yaitu penelitian deskriptif kualitatif. Hasil penelitian ini menunjukkan bahwa penguatan pendanaan untuk industri perikanan cukup memberikan manfaat bagi pelaku usaha perikanan ada kemudahaan akses pendanaan yang diperoleh. Pemberdayaan dilakukan pemerintah daerah dalam hal pengemasan serta membantu meningkatkan promosi produk usaha pengolahan hasil perikanan ke berbagai daerah, pemberian bantuan sarana dan prasarana usaha untuk pelaku usaha industri abon ikan cukup efektif tetapi pelaksanaan pembinaan yang dilakukan pemerintah daerah belum terlaksana secara berkelanjutan guna meningkatkan nilai tambah ekonomis pada usaha yang telah dibina oleh pemerintah.
\end{abstract}

Kata Kunci : pemberdayaan, masyarakat, pengelolaan hasil perikanan 


\section{A. PENDAHULUAN}

Keberadaaan otonomi daerah sebagai roh asas desentralisasi dalam penyelenggaraan pemerintahan lahir sebagai jawaban atas tuntutan masyarakat, pada hakekatnya merupakan penerapan konsep teori areal division of power yang membagi kekuasaan negara secara vertikal. Dalam konteks ini, kekuasaan akan terbagi antara pemerintah pusat di satu pihak dan pemerintah daerah di lain pihak, yang secara legal konstitusional tetap dalam kerangka negara kesatuan republik Indonesia. Kondisi ini membawa implikasi terhadap perubahan paradigma pembangunan yang dewasa ini diwarnai dengan isyarat globalisasi. Konsekuensinya, berbagai kebijakan publik dalam kegiatan pemerintahan, pembangunan dan pelayanan publik menjadi bagian dari dinamika yang harus direspons dalam kerangka proses demokratisasi, pemberdayaan masyarakat dan kemandirian lokal.

Melalui keberadaan otonomi daerah, dunia usaha di daerah akan menghadapi suatu perubahan besar yang sangat berpengaruh terhadap iklim berusaha atau persaingan di daerah. Oleh karena itu, setiap pelaku bisnis di daerah dituntut dapat beradaptasi menghadapi perubahan tersebut. Disuatu sisi perubahan itu akan memberikan kebebasan sepenuhnya bagi daerah dalam menentukan sendiri kegiatan-kegiatan yang produktif dan dapat menghasilkan nilai tambah yang tinggi sehingga dapat memberikan sumbangan terhadap masukan pendapatan asli daerah, salah satunya adalah industri-industri dengan bahan baku berasal dari sumberdaya alam daerah tersebut. Diharapkan industri-industri di daerah dapat berkembang dengan memanfaatkan sumberdaya yang tersedia sehingga mempunyai daya saing tinggi dibandingkandengan daerah-daerah lain. Bagi pengusaha setempat, pembangunan dan pengembangan industri-industri tersebut merupakan peluang bisnis besar, baik dalam arti membangun perusahaan di industri tersebut atau perusahaan $\mathrm{di}$ sektor-sektor lain yang terkait dengan industri tersebut. Dari sisi lain, jika tidak ada kesiapan yang matang dari pelaku-pelaku bisnis daerah, maka pemberlakuan otonomi daerah akan menimbulkan ancaman besar bagi mereka untuk dapat bertahan menghadapi persaingan dari luar daerah atau bahkan dari luar negeri. Dengan arti, tantangan yang pasti dihadapi setiap pelaku bisnis di daerah pada masa mendatang adalah bagaimana pelaku bisnis di daerah dapat memanfaatkan kesempatan tersebut sebaikbaiknya.

Menyadari kenyataan inilah pemerintah berupaya seoptimal mungkin untuk memajukan sektor riil berskala kecil. Tidak terkecuali pada sektor perikanan industri pengolahan ikan di Indonesia tergolong tinggi dari hasil perikanan. Sebagian besar pengolahan ikan dikelola secara tradisional hal ini dikarenakan pengolahan modern membutuhkan persyaratan yang sulit dipenuhi industri kecil termasuk didalamnya kualitas bahan baku bermutu tinggi kualitas kemasan dan teknologi pengelolaanya. Untuk ikut bersaing industri pengolahan ikan skala kecil ini membutuhkan bantuan modal dan pembinaan yang berkelanjutan untuk menghasilkan produk industri ikan olahan yang ditinjau dari segi ekonomis menguntungkan, dari segi teknis bisa dilaksanakan, dan segi ekologis dapat diterima masyarakat.

Industri perikanan menjadi salah satu komoditi yang banyak diolah di Indonesia dengan jumlah ikan yang luar biasa melipah dari kekayaaan laut Indonesia khususnya di daerah sulawasi selatan yang dikenal memiliki kedalam laut yang dalam mencapai ribuan meter dengan berbagai macam spesies dan jenis ikan yang beraneka ragam. Menjadi tatangan buat pemerintah untuk membantu masyarakat sekitar pesisir laut untuk meningkatkan produktifitas dalam hal pengelolaan hasil laut.

Konsep pemberdayaan masyarakat sendiri mendapatkan penekanan yang lebih khusus. Terutama pada model intervensi pengembangan masyarakat.Sebagai suatu konsep pemberdayaan masyarakat mempunyai berbagai definisi. suatu pemberdayaan (empowerment), pada intinya, ditujukan guna membantu klien memperoleh 
daya untuk mengambil keputusan dan menentukan tindakan yang akan ia lakukan yang terkait dengan diri mereka, termasuk mengurangi efek hambatan pribadi dan sosial dalam melakukan tindakan (Adi, 2013).

Hal ini yang menjadi kunci untuk membantu meningkatkan pendapatan masyarakat dalam mengelola hasil laut yakni melalui pemberdayaan. Maka perlu untuk mengetahui betuk pelaksanaan pemberdayaan masyarakat dalam pengelolaan industri perikanan di Kelurahan Sumpang Binagae Kabupaten Barru.

\section{B. KONSEP PEMBERDAYAAN}

Pemberdayaan sebagai proses pengambilan keputusan oleh orang orang yang secara konsekuen melaksanakan keputusan tersebut. Orang orang yang telah mencapai tujuan kolektif diberdayakan melalui kemandiriannya, bahkan merupakan "keharusan" untuk lebih diberdayakan melalui usaha mereka sendiri dan akumulasi pengetahuan, ketrampilan dan sumber lainnya dalam rangka mencapai tujuan mereka tanpa bergantung pada pertolongan eksternal. Namun demikian, McArdle mengimplikasikan hal tersebut bukan untuk mencapai tujuan, melainkan makna pentingnya proses dalam pengambilan keputusan (Hikmah, 2010).

Selanjutnya terdapat tujuan dari pemberdayaan merunjuk pada keadaan atau hasil yang ingin dicapai oleh sebuah perubahan sosial yaitu masyarakat yang berdaya, memiliki kekuasaan atau pengetahuan dan kemampuan dalam memenuhi kebutuhan hidupnya baik yang bersifat fisik, ekonomi, maupun sosial seperti memiliki kepercayaan diri, mampu menyampaikan aspirasi, mempunyai mata pencaharian, berpastisipasi dalam kegiatan sosial dan mandiri dalam melaksanakan tugas-tugas kehidupannya. (Soeharto, 2005).

\section{PEMBERDAYAAN MASYARAKAT DESA.}

Menurut (Zunadi, 2010) mengartikan pemberdayaan dalam konteks masyarakat sebagai suatu proses yang membangun Pemberdayaan Masyarakat Dalam Pengelolaan Hasil Perikanan Di Kelurahan Sumpang Binangae Kabupaten Barru - Zulfan Nahruddin ${ }^{1}$ manusia atau masyarakat melalui pengembangan kemampuan masyarakat, perubahan perilaku masyarakat, dan pengorganisasian masyarakat. Dari definisi tersebut terlihat ada 3 tujuan utama dalam pemberdayaan masyarakat yaitu mengembangkan kemampuan masyarakat, mengubah perilaku masyarakat, dan mengorganisir diri masyarakat. Kemampuan masyarakatyang dapat dikembangkan tentunya banyak sekali seperti kemampuan untuk berusaha, kemampuan untuk mencari informasi, kemampuan untuk mengelola kegiatan, kemampuan dalam pertanian dan masih banyak lagi sesuai dengan kebutuhan atau permasalahan yang dihadapi oleh masyarakat.

Konsep pemberdayaan dalam wacana pembangunan masyarakat selalu dihubungkan dengan konsep mandiri, partisipasi, jaringan kerja, dan keadilan. Pada dasarnya pemberdayaan diletakkan pada kekuatan tingkat individu dan sosial. Partisipasi merupakan komponen penting dalam pembangkitan kemandirian dan proses pemberdayaan. Sebaiknya, orang-orang harus terlibat dalam proses tersebut sehingga mereka dapat lebih memperhatikan hidupnya untuk memperoleh rasa percaya diri, memiliki harga diri dan pengetahuan untuk mengembangkan keahlian baru. Prosesnya dilakukan secara kumulatif sehingga semakin banyak ketrampilan yang dimiliki seseorang, semakin baik kemampuan berpastisipasinya (Anwar,2007).

\section{PENDEKATAN PEMBERDAYAAN MASYARAKAT PESISIR}

Pendekatan pemberdayaan yang bertujuan agar masyarakat tampil sebagai pelaku utama bagi pemecahan masalah dan pemenuhan kebutuhannya sendiri. Kemampuan masyarakat untuk mewujudkan dan mempengaruhi arah serta pelaksanaan suatu program ditentukan dengan mengandalkan power yang dimilikinya Sehingga pemberdayaan (Empowerment) merupakan central theme atau jiwa partisipatif yang sifatnya aktif dan kreatif Setyoko (dalam mardijono 2008).

Melalui konteks partisipasi masyarakat dalam perencanaan, pelaksanaan, pengawasan, pengembangan dan pelestarian pembangunan ekonomi merupakan salah satu pendekatan 
yang digunakan pada program pemberdayaan ekonomi masyarakat pesisir. Pembangunan dan Pemberdayaan Masyarakat di artikan sebuah usaha dalam meningkatkan segala kemampuan baik dari segi Sumber Daya Manusia (SDM) atatu Sumber Daya Alam (SDA), hal ini dilakukan dalanm rangka mensejahterkana dan memanusiakan masyarakat yang sering kali hanya dijadikan batu loncatan untuk meraih sebuah kesuksesan baik oleh masyarakat, kelompok maupun individu. (Usman, 2004)

.Selain itu, kemandirian (keswadayaan) dan kemitraan sudah banyak dibuktikan bahwa suatu rencana akan dapat dilaksanakan secara efektif apabila semua pihak yang melaksanakan dilibatkan di dalamnya. Dalam pelaksanaan pemberdayaan masyarakat tidak lepas dari potensi pengembangan sosial artinya dalam upaya membangun dan memberdayakan masyarakat pesisir hendaknya juga memperhatikan berbagai hal yang terkait dengan keberdayaan masyarakat itu sendiri dalam rangka untuk meningkatkan usahanya pada orientasi pasar selanjutnya dapat memberikan impuls dalam mendukung ketahanan pangan. Pemberdayaan perikanan rakyat dapat dilakukan melalui dukungan kelembagaan, permodalan, serta program kemitraan terpadu yang langsung menyentuh kebutuhan nelayan merupakan solusi strategis menyelesaikan masalah perekonomian masyarakat pesisir.

\section{E. PENGELOLAAN HASIL PERIKANAN}

Dirjen Perikanan menyebutkan karakteristik dari pengolahan ikan tradisional, antara lain :

a. Kemampuan pengetahuan pengolah rendah dengan keterampilan yang diperoleh secara turun-temurun.

b. Tingkat sanitasi dan higienis rendah, sesuai dengan keadaan lingkungan di sekitarnya yang umumnya tidak memiliki sarana air bersih.

c. Permodalannya sangat lemah.

d. Peralatan yang digunakan sangat sederhana. e. Pemasaran produk hanya terbatas pada pasaran lokal.

Pengasinan atau penggaraman dalam mengawetkan ikan merupakan cara yang terbanyak dilakukan. Tujuannya adalah agar kandungan air dalam daging ikan terserap sehingga aktivitas mikrooganisme (bakteri pembusuk) dapat terhenti. Selain itu, larutan garam juga dapat menyebabkan osmose pada sel-sel mikroorganisme yang menjadikan kurangnya kadar air pada sel bakteri. Dengan begitu bakteri akan mati. Saat ini belum banyak yang berminat mengembangkan usaha pengolahan ikan asin secara tradisional tersebut untuk diekspor. Pengolahan yang ada saat ini masih sebatas untuk memenuhi kebutuhan lokal, sehingga potensi pasar ekspor hasil olahan ikan asin tradisional belum dimanfaatkan secara maksimal. Namun kenyataannya produksi ikan asin menurun, penyebabnya antara lain : musim, kenaikan harga ikan segar, dan kenaikan BBM.

Menurut (Afrianto dan Liviawaty, 2005), proses penggaraman dapat dilakukan dengan cara : (1) Penggaraman kering (Dry salting), penggaraman kering baik digunakan untuk ikan yang berukuran besar maupun kecil. Penggaraman menggunakan garam berbentuk kristal. Ikan yang akan diolah ditaburi garam lalu disusun secara berlapislapis. Setiap lapisan ikan diselingi lapisan garam. Selanjutnya lapisan garam akan menyerap keluar cairan di dalam tubuh ikan. (2) Penggaraman basah (Wet salting), metodenya menggunkan larutan garam sebagai media untuk ikan. Larutan garam akan menghisap cairan tubuh ikan (sehingga konsentrasinya menurun) dan ion-ion garam akan segera masuk ke dalam tubuh ikan. (3) Kech salting, metode ini hampir serupa dengan penggaraman kering. Bedanya cara ini tidak menggunakan bak kedap air. Ikan hanya ditumpuk dengan menggunakan keranjang. (4) Penggaraman diikuti proses perebusan Ikan pindang merupakan salah satu contoh ikan yang mengalami proses penggaraman yang diikuti perebusan. Dalam hal ini, proses pembusukan ikan dicegah dengan cara merebusnya dalam larutan garam jenuh. Jenis ikan yang biasanya digunakan untuk produksi ikan asin adalah ikan tiga waja dan ikan kuniran. Perbedaan jenis, ukuran atau cara pengolahan ikan akan memberikan rasa asin 
yang berbeda terhadap produk akhir ikan asin.

Pengasapan merupakan salah satu cara dalam melakukan pengawetan ikan yang umum dilakukan oleh pengolah ikan di Indonesia. Metode ini nantinya akan memberikan warna serta rasa keasapasapan yang khas pada ikan tersebut. Dengan memanfaatkan asap dari kayu yang dibakar sekaligus panas yang dihasilkan pada waktu pengasapan (yang juga telah disertai dengan bumbubumbu), maka aktivitas mikroorganisme dan enzim-enzim perusak daging ikan dapat dicegah dan dihentikan.

Menurut Afrianto dan Liviawaty (2005), pada dasarnya proses pengasapan ikan merupakan gabungan aktivitas penggaraman, pengeringan dan pengasapan. Adapun tujuan utama proses pengasapan adalah untuk membunuh bakteri dan membantu mempermudah melekatnya partikel-partikel asap waktu proses pengasapan. Yang dapat meningkatkan daya awet ikan dalam proses pengasapan bukanlah rasa melainkan unsur-unsur kimia yang terkandung di dalam asap.

Ada beberapa cara pengasapan, yaitu pengasapan dingin, pengasapan panas dan pengasapan langsung atau tidak langsung. Jenis ikan yang diasap pun beraneka ragam mulai ikan bandeng hingga ikan salmon. Pewarnaan, rasa, dan aroma ikan asap tergantung pada komponen yang dihasilkan pembakaran. Hal ini juga tergantung pada jenis kayu yang digunakan. Senyawa asam organik dalam asap akan memberikan warna. Ikan asap memiliki beberapa nilai tambah antara lain : mudah diolah (digoreng, digulai, ditauco atau dipindang), memiliki aroma yang merangsang selera, mengandung protein, gizi, dan kalsium yang tinggi, harga relatif lebih murah dibanding ikan sejenis, ikan enak seperti ikan segar.

Selanjutnya, fillet ikan merupakan cara pengolahan ikan setengah jadi. Biasanya ada proses lanjutan hingga menjadi produk ikan jadi. Dari fillet ikan ini bisa digunakan untuk berbagai keperluan, langsung digoreng atau dibentuk menjadi berbagai macam produk yang lebih menarik dengan bahan tambahan, maka fillet ikan mampu disimpan dalam jangka waktu yang lama untuk dikonsumsi.

Produk fillet ikan kebanyakan langsung diterima oleh pengepul/pemasok di beberapa daerah untuk diolah kembali. Saat ini telah banyak investor yang mencoba bekerjasama dengan pengolah fillet ikan. Pembuatan fillet ikan sangat menguntungkan banyak pihak dan meningkatkan efisiensi secara keseluruhan. Konsumen dapat memperoleh produk yang praktis sehingga waktu yang dibutuhkan untuk memasak menjadi lebih cepat. Sementara bagi produsen, pembuatan fillet merupakan upaya memperoleh nilai tambah, karena penjualan fillet harganya lebih tinggi daripada ikan dijual utuh.

Selain itu dengan memproduksi fillet dapat memperluas upaya diversifikasi usaha khususnya dari pemanfaatan limbah. Kepala ikan, jeroan dan tulang ikan dalam jumlah banyak dapat diolah kembali menjadi tepung ikan, pupuk atau produk lainnya. Kulit ikan dapat diolah menjadi kerupuk kulit ikan atau dijual kepada para penyamak kulit yang saat ini masih kekurangan bahan baku. Jadi jika dilihat secara keseluruhan terjadi peningkatan efisiensi yang luar biasa karena tidak ada limbah terbuang percuma. Fillet ikan saat ini telah dapat ditemui di pasar tradisional, meskipun jumlahnya belum banyak. Pengawetan ikan dapat dilakukan dengan pengalengan, yaitu salah satu cara penyimpanan dan pengawetan bahan pangan yang dikemas dengan (kaleng) dan kemudian disterilkan, sehingga diperoleh produk pangan yang tahan lama dan tidak mengalami kerusakan baik fisik, kimia maupun biologis. Kandungan protein yang cukup tinggi pada ikan menyebabkan ikan mudah rusak bila tidak segera dilakukan pengolahan dan pengawetan. Pengawetan bertujuan untuk memperpanjang masa simpan bahan pangan.

Salah satu diantara produk olahan ikan adalah abon ikan. Abon merupakan produk olahan yang sudah cukup dikenal luas oleh masyarakat. Dewan Standarisasi Nasional mendefinisikan abon sebagai suatu jenis makanan kering berbentuk khas yang terbuat dari daging yang direbus, disayat-sayat, dibumbui, digoreng dan dipres. Pembuatan abon menjadi alternatif pengolahan ikan dalam rangka penganekaragaman produk 
perikanan dan mengantisipasi melimpahnya tangkapan ikan di masa panen. Abon ikan merupakan jenis makanan olahan ikan yang diberi bumbu, diolah dengan cara perebusan dan penggorengan. Produk yang dihasilkan mempunyai bentuk lembut, rasa enak, bau khas, dan mempunyai daya awet yang relatif lama.

\section{F. METODE PENELITIAN}

Lokasi penelitian akan dilaksanakan di Kelurahan Sumpang Binangae Kabupaten Barru dengan fokus penelitian yakni pemberdayaan masyarakat dalam pengelolaan hasil perikanan. Jenis penelitian yang digunakan adalah pendekatan deskriptif kualitatif, yaitu dimaksudkan untuk pengukuran yang cermat terhadap studi kasus fenomena sosial tertentu. Sumber data penelitian ini terutama disaring dari sumber data primer dan data sekunder dengan proporsi sesuai dengan tujuan penelitian ini. selanjutnya Teknik pengumpulan data yang dipergunakan dalam penelitian ini yaitu : observasi, yaitu melakukan pengamatan langsung dilapangan sesuai dengan obyek yang diteliti; interview, yaitu wawancara langsung kepada informan dengan menggunakan catatan dan pedoman wawancara; Dokumentasi, yaitu kajian literatur/kepustakaan, dokumen, dan sumber tertulis lainnya yang ada kaitannya dengan kebutuhan data dan informasi dalam penelitian ini. (Sugiyono, 2011). Analisis data dilakukan dengan menelaah data yang diperoleh dari berbagai sumber atau informasi dari hasil penelitian baik yang diperoleh melalui data primer maupun data sekunder yang dilakukan secara deskriftif kualitatif. Teknik analisis data dalam penelitian ini menggunakan model Miles dkk, dimana data yang diperoleh dianalisis secara kualitatif, yakni analisis data dilakukan secara interaktif dan berlangsung secara terus menerus sampai tuntas. Rangkaian prosesnya mencakup reduksi data, penyajian data, dan verifikasi data. (Sugiyono, 2011).

\section{G. HASIL DAN PEMBAHASAN}

Merujuk

pada

tujuan

dari pemberdayaan mewujudkan pada keadaan atau hasil yang ingin dicapai oleh sebuah perubahan sosial yaitu masyarakat yang berdaya, memiliki kekuasaan atau pengetahuan dan kemampuan dalam memenuhi kebutuhan hidupnya baik yang bersifat fisik, ekonomi, maupun sosial seperti memiliki kepercayaan diri, mampu menyampaikan aspirasi, mempunyai mata pencaharian, berpastisipasi dalam kegiatan sosial dan mandiri dalam melaksanakan tugas-tugas kehidupannya. Maka bentukbentuk pemberdayaan yang di lakukan pemerintah Kabupaten Barru melalui :

\section{Penguatan Pendanaan}

Khusus untuk industri pengolahan ikan pemerintah juga memberikan kemudahan dalam memperoleh pendanaan secara cepat, tepat, dan murah serta memberikan kemudahan dalam pelayanan sesuai dengan ketentuan. Seperti yang di katakan oleh kepala bidang Kelembagaan dan Pengawasan Dinas Kelautan dan Perikanan Kabupaten Barru mengatakan bahwa :

"Kami dari dinas kelautan dan perikanan juga mempunyai peranan membantu dalam memberikan bantuan penguatan modal bagi pengusaha pengolahan ikan yaitu dengan memberikan dana yang dapat diambil dari koprasi dengan bunga yang rendah jadi pelaku usaha yang sedah memenuhi ketentuan dapat langsung ke koprasi untuk memperoleh bantuan dana" (Wawancara, NA)

Dari hasil wawancara tersebut dapat kita ketahui bahwa untuk pembiayaan usaha kecil menengah khususnya industri pengolahan ikan di berikan akses yang mudah untuk memperoleh bantuan diantaranya melalui penguatan modal usaha yang merupakan salah satu tahap dari program Pemberdayaan Ekonomi Masyarakat Pesisir yang dilakukan oleh Dinas Kelautan dan Perikanan.

Untuk mempermudah pengembangan usaha pengolahan ikan ini pemerintah memberikan bantuan modal, kredit lunak, dan kemudahan dalam memperoleh pendanaan

Pemberdayaan Masyarakat Dalam Pengelolaan Hasil Perikanan

Di Kelurahan Sumpang Binangae Kabupaten Barru - Zulfan Nahruddin 
melalui bank-bank pelaksana yang telah berkoordinasi dengan dinas terkait dalam hal ini Dinas Koprasi Perindustriaan dan Perdagangan. Selain itu lembaga pencairan modal lainnya non bank adalah koprasi yang juga memberikan kemudahan akses pembiayaan dengan bunga yang rendah melalui koordinasi dengan Dinas Kelautan dan Perikanan. Jadi dari kedua Dinas tersebut pemerintah daerah memberikan akses yang mudah bagi para pelaku Usaha Kecil Menengah untuk memperoleh modal usaha dan juga bantuan modal untuk mengembangkan usahanya dengan prosedur yang mudah. Berdasarkan pengamatan di lapangan salah seorang pelaku usaha industri pengolahan ikan mengatakan bahwa :

"Saya pernah memperoleh bantuan dana sebesar 10 juta untuk kelompok usaha kami mengajukan proposal kepada dinas kelautan dan perikanan untuk membeli alat tempat pengeringan ikan dan mesin kapal walaupun pencairan dana lama baru keluar tetapi sangat berguna bagi kami"

\section{(Wawancara, SL)}

Dari beberapa hasil wawancara diatas penulis berpendapat bahwa Bantuan pendanaan untuk industri perikanan cukup memberikan ruang kepada para pelaku usaha untuk mengembangkan usahanya karena untuk mendapatkan dana bantuan pemerintah memfasilitasi dan memediasi bantuan pendanaan untuk para pelaku usaha pengolahan ikan melalui kerjasama dengan bank pelaksana dan koprasi yang ditunjuk pemerintah dalam pendanaan bagi para pelaku usaha. Kesempatan inilah yang seharusnya dimanfaatkan oleh para pelaku usaha pengolahan ikan tetapi berdasarkan pengamatan dilapangan hanya sebagian kecil pelaku usaha pengolahan ikan yang memanfaatkan bantuan pendanaan dan permodalan tersebut.

\section{Mendorong Pemasaranhasil perikanan}

Peran pemerintah daerah dalam pemasaran hasil produksi Usaha kecil menengah khususnya dinas koprasi perindustriaan dan perdagangan memberikan kesempatan kepada para pelaku usaha untuk mempromosikan hasil produk usahanya baik di daerah maupun di tingkat provinsi melaksanakan suatu pameran hasil usaha, sehingga dapat dikenal oleh masyarakat luas, bukan hanya di satu daerah saja tetapi dapat juga di kenal daerah lain atau provinsi lain. Hal ini sesuai dengan yang diungkapkan oleh kepala bidang UMKM Dinas Koprindag Kabupaten Barru, yang mengatakan bahwa:

"Untuk membantu pemasaran produk ukm kami memfasilitasi dan mengundang pelaku industri untuk mempromosikan produk-produk unggulan daerah termasuk abon ikan dalam pameran di tingkat daerah maupun di tingkat provinsi hal ini dapat membantu pelaku ukm dalam memperkenalkan jenis produknya" (wawancara, DJ)

Pemerintah membantu mendukung promosi usaha kecil menengah termasuk usaha industry perikanan. Pemasaran merupakan tanggung jawab bersama antara pelaku usaha dan pemerintah daerah, salah satu hal yang perlu diperhatikan adalah pengemasan produk yang dihasilkan sebelum produk tersebut dipasarkan. Bentuk kemasan dapat menarik minat konsumen sehingga perlu diadakan pelatihan pembuatan kemasan yang menarik dan kemudian dukungan promosi produk Usaha kecil menengah, melalui pameran, akan dapat membantu memperluas jaringan pemasaran, dan distribusi.

pemasaran hasil industri olahan ikan ini hanya dapat dilakukan untuk olahan jadi yaitu industri abon ikan hal ini dikarenakan pemasaran abon ikan belum dikenal luas masyarakat disinilah peran pemerintah untuk membantu mempromosikan hasil usaha tersebut agar dapat memperluas pasar di luar daerah berbeda halnya dengan pemasaran ikan kering atau ikan asin dengan mudah dikenal oleh masyarakat dan mempunyai pasar tersendiri sehingga dapat dengan mudah didistribusikan dalam skala besar keluar daerah seperti Pinrang dan Sidrap tanpa perlu untuk mendapat dukungan promosi hanya saja kendala dari pemasaran ikan kering ini adalah jumlah produksi yang 
kadang-kadang tidak menentu karena harus bergantung pada produktifitas ikan di laut dan kondisi cuaca karena industri pengolahan ikan ini sangat bergantung pada kondisi cuaca dan pemanasan sinar matahari.

\section{Membantu sarana prasarana}

Untuk industri pengeringan ikan atau pengasinan ikan pemerintah daerah dalam hal ini Dinas Kelautan dan Perikanan memberikan bantuan berupa sarana tempat pengeringan ikan atau yang lebih di kenal masyarakat Sumpang Binangae dengan istilah Para-para tempat penyimpanan ikan yang akan dikeringkan berbentuk segi panjang yang terbuat dari kayu atau bambu dan jaring yang dapat memuat ikan dalam jumlah banyak.

Berdasarkan data yang penulis temukan dilapangan pemberian bantuan berupa sarana "para-para" tersebut kurang maksimal pemanfaatannya bagi sebagian masyarakat nelayan yang mengelola ikan kering. Hal ini dijelaskan oleh nelayan yang juga pemilik usaha pengeringan ikan ini mengatakan bahwa :

"Pemerintah pernah memberikan kita bantuan berupa alat pembuatan para-para tetapi kayu yang diberikan terlalu berat untuk diangkat sementara kalau turun hujan ikan harus cepat dipindahkan jadi kayu tersebut kami ganti dengan bambu agar ringan mengankatnya sedangkan kayu yang diberikan itu kami gunakan untuk tempat duduk" (wawncara, $A L$ )

Berdasarkan wawancara dan pengamatan penulis dilapangan menunjukkan bahwa pemberian bantuan sarana usaha untuk pelaku usaha industri pengolahan abon ikan sangat baik dan efektif karena sarana yang diberikan betulbetul dimanfaatkan dengan baik hal ini didukung oleh pengadaan pembinaan dan pelatihan. Berbeda halnya dengan pelaku usaha pengeringan ikan yang kurang efektif untuk pemberian sarana tempat pengeringannya karena kayu yang digunakan dirasakan oleh pelaku usaha

Pemberdayaan Masyarakat Dalam Pengelolaan Hasil Perikanan

Di Kelurahan Sumpang Binangae Kabupaten Barru - Zulfan Nahruddin ${ }^{1}$ tidak sesuai untuk digunakan sebagai tempat pengeringan ikan terlalu berat sehingga sedikit menyulitkan proses pemindahan jika cuaca kurang mendukung.

\section{Pemberian Pembinaan dan Pelatihan}

Dalam melakukan pembinaan pemerintah daerah dalam hal ini dinas kelautan dan perikanan memfasilitasi sejumlah pelaku usaha pengolahan ikan dan masyarakat nelayan untuk mengikuti berbagai pelatihan pengolahan hasil perikanan. Hal ini sesuai dengan yang dikatakan pengusaha abon ikan tuna yang mengatakan bahwa:

"Pelatihan yang saya ikuti dengan beberapa anggota adalah pelatihan pembuatan abon, pelatihan tentang olahan yang higienis, dan pembuatan kemasan yang menarik untuk mengikuti pelatihan tersebut semua difasilitasi oleh pemerintah baik transportasi maupun komsumsinya selama kita mengikuti pelatihan tersebut"

(Wawancara, SL)

Berdasarkan pengamatan penulis dilapangan dan wawancara dengan para pelaku usaha pengolahan ikan peran pemerintah dalam melakukan pembinaan terkhusus untuk industri pengolahan ikan hanya menyentuh usaha pengolahan ikan abon saja hal ini sesuai dengan yang dijelaskan oleh kepala bidang pemasaran dan pengawasan Dinas Kelautan dan Perikanan Kabupaten Barru, yang mengatakan bahwa :

"Untuk masyarakat yang mengembangkan usaha pengolahan ikan kami akan melakukan kunjungan teknis ketempat pengolahan ikan kemudian setelah itu kami melakukan pembinaan secara bertahap kemudian barulah kami memfasilitasi untuk pengadaan sarana usaha dan alat-alat yang dibutuhkan, setelah itu kami dapat memberikan bantuan penguatan modal untuk pengembangan usaha"

(Wawancara, NA)

Dari hasil wawancara di atas penulis berpendapat bahwa pembinaan usaha memang seharusnya untuk pelaku usaha yang memiliki keseriusan untuk mengembangkan 
usahanya secara berkelanjutan dan betulbetul berproduksi agar hasil dari pembinaan ini tidak hanya asal melakukan pembinaan saja tetapi menghasilkan sebuah output usaha yang memberikan nilai tambah ekonomis bagi masyarakat dan dapat membuka lapangan kerja.

\section{H. PENUTUP}

Pemberdayaan masyarakat dalam pengelolaan hasil perikanan dilakukan memediasi pemberikan bantuan permodal dan kredit lunak baik untuk sentra atau kelompok usaha maupun khusus untuk satu industri pencairan dananya melalui bankbank pelaksana dan juga koprasi. Selanjutnya dalam pemasaran hasil produksi khususnya Dinas Koprasi Perindustriaan dan Perdagangan memberikan kesempatan kepada para pelaku usaha untuk mempromosikan hasil produk usahanya namun untuk kelurahan Sumpang Binangae hanya industri pengolahan abon ikan yang memenuhi standar untuk dipromosikan.

Pemerintah daerah memberikan bantuan sarana usaha kepada para pelaku usaha pengolahan ikan namun fakta yang ditemukan dilapangan hanya industri abon ikan yang dapat mengoptimalkan bantuan sarana atau alat-alat yang diberikan tetapi untuk Usaha Pengeringan ikan asin sarana yang berikan belum tepat sasaran. Melalui pelatihan teknik produksi dan pengolahan merupakan pengembangan ekonomi masyarakat pesisir yaitu memfasilitasi para pelaku usaha untuk mendapatkan pelatihan yang diadakan ditingkat provinsi untuk meningkatkan produktifitas masyarakat pesisir dengan mengolah ikan agar memiliki nilai tambah ekonomi dan meningkatkan kualitas produk.

\section{DAFTAR PUSTAKA}

Adi, Isbandi Rukminto. 2013. Intervensi Komunitas dan Pengembangan Masyarakat sebagai upaya pemberdayaan Masyarakat. Jakarta: PT. Raja Grafindo Persada.
Ikan. Yogyakarta : Kanisius.

Anwar, 2007. Manajemen Pemberdayaan Perempuan. Bandung : Alfabeta

Hikmat, Harry. 2010. Strategi Pemberdayaan Masyarakat. Bandung : Humaniora Utama Press.

Mardijono, 2008. Persepsi Dan Partisipasi NelayanTerhadap Pengelolaan Kawasan Konservasi Laut Kota Batam, Tesis Manajemen Sumberdaya Pantai. (Tesis) Semarang : Universitas Diponegoro

Sugiyono, 2011. Metode Penelitian Kuantitatif Kualitatif dan $R \& D$. Bandung : Alfabeta.

Suharto, Edi. 2005. Membangun Masyarakat, Memberdayakan Rakyat. Bandung : PT.Retika Adhitama.

Usman, Sunyoto. 2004. Pembangunan dan Pemberdayaan Masyarakat. Yogyakarta : Pustaka Pelajar

Zunadi, Muhammad. 2010. Pemberdayaan Masyarakat.http://www.rumahzakat.o rg/. diakses 10 Februari 2014. 